\title{
INISIASI MENYUSUI DINI
}

\author{
Nurhaida Br Kaban*)
}

Surel: mumunrieto@gmail.com

\begin{abstract}
The purpose of this study was to determine the level of knowledge of primigravida pregnant women about early breastfeeding initiation at the Sundari General Hospital Medan. The research design used is descriptive. The sample technique used is probability simple random sampling with the number of samples is 65 people. Data were obtained by using questionnaires that were distributed and filled directly by the respondents. The data analysis used is univariate analysis that is to know systematically picture of pregnant primigravida mother about Initiation of Early Breastfeeding at Sundari General Hospital Medan. The results showed that most of primigravida mother's knowledge about early initiation of breastfeeding was less that of 42 people $(64,6 \%)$ and small knowledge of primigravida mother about early initiation of breastfeeding is 10 people (15,4\%). It is advisable to health agencies should as often as possible to counseling related to mother and child health, especially about the importance of early breastfeeding initiation to pregnant women in order to improve the knowledge of pregnant women about the benefits of early breastfeeding initiation.
\end{abstract}

Keywords: Knowledge of Pregnant Women, Early Breastfeeding Initiation.

\section{PENDAHULUAN}

$\mathrm{P}$ emeliharaan kesehatan bayi dan anak harus ditujukan untuk mempersiapkan generasi yang akan datang yang sehat, cerdas, dan berkualitas serta untuk menurunkan angka kematian bayi dan anak. Upaya pemeliharaan kesehatan anak dilakukan sejak janin masih dalam kandungan, dilahirkan, setelah dilahirkan, dan sampai berusia 18 (delapan belas) tahun. Upaya pemeliharaan kesehatan anak antara lain diha ${ }^{1}$ rapkan untuk dapat menurunkan angka kematian anak. Indikator angka kematian yang berhubungan dengan anak adalah Angka Kematian Neonatal (AKN),

* Nurhaida Br Kaban, SST, M.Kes, Dosen STIKES Flora Medan
Angka Kematian Bayi (AKB) dan Angka Kematian Balita (AKABA) (Profil Kesehatan Indonesia, 2013).

Hasil Survei Demografi dan Kesehatan Indonesia (SDKI) tahun 2012, secara nasional AKN pada tahun 2012 sebesar 19 per 1000 kelahiran hidup $(\mathrm{KH})$. Angka ini menurun dibandingkan tahun 2007 yaitu 20 per 1000 KHdan di tahun 2002yaitu 23 per 1000 KH. AKB juga mengalami penurunan dibandingkan hasil SDKI tahun 2007 dan 2002 dimana AKB tahun 2012 adalah 32 per $1000 \mathrm{KH}$ sedangkan pada tahun 2007 sebesar 35 per 1000 KH dan tahun 2002 sebesar 45 per $1000 \mathrm{KH}$. AKABA juga mengalami penurunan dimana hasil SDKI tahun 2012 AKABA 40 per $1000 \mathrm{KH}$, 
sedangkan tahun 2007 AKABA 45 per $1000 \mathrm{KH}$ dan tahun 2002 AKABA 58 per $1000 \mathrm{KH}$. Menurut laporan SDKI 2012, untuk Propinsi Sumatera, AKN dan AKB di Propinsi Sumatera Utara menduduki posisi kedua tertinggi setelah Aceh, sedangkan AKABA menduduki peringkat pertama. Dimana AKN 26 per $1000 \mathrm{KH}, \mathrm{AKB} 40$ per $1000 \mathrm{KH}$ dan AKABA 54 per $1000 \mathrm{KH}$ (Laporan SDKI, 2012).

Berdasarkan hasil Suvey Demografi Kesehatan Indonesia (SDKI) yang dilakukan oleh BPS setiap 5 (lima) tahunan, diperoleh hasil bahwa AKB di Sumatera Utara mengalami penurunan dari tahun 1994 sebesar 61/1.000 KH, turun menjadi 42/1.000 KH pada SDKI tahun 2002. Namun pada tahun 2007 mengalami kenaikan menjadi 46/1.000 KH dan ada tahun 2012, menurun kembali menjadi sebesar 40/1.000 KH (Profil Kesehatan Sumatera Utara, 2012).

Pola SDKI 2012 sama dengan pola SDKI 2007 yaitu lebih dari 3/4 dari semua kematian balita terjadi dalam tahun pertama kehidupan anak dan mayoritas kematian bayi terjadi pada periode neonatus. Perhatian kepada upaya penurunan Angka Kematian Neonatal (1-28 hari) menjadi penting karena kematian neonatal memberi konstibusi terhadap $56 \%$ kematian bayi (Laporan SDKI, 2012).

Walaupun terjadi penurunan AKB baik secara nasional maupun provinsi Sumatera Utara tetapi masih lambat dan masih jauh dari target MDGs 2015. Untuk mencapai target penurunan AKB pada MDGs 2015 yaitu sebesar 23 per 1000 kelahiran hidup maka peningkatan akses dan kualitas pelayanan bagi bayi baru lahir (neonati) menjadi prioritas utama. Komitmen global dalam MDGs menetapkan target terkait kematian anak yaitu menurunkan angka kematian anak hingga dua per tiga dalam kurun waktu 1990-2015 (Profil Kesehatan Indonesia, 2013).

Upaya untuk mencegah kematian bayi baru lahir yang sudah disosialisakan di Indonesia sejak Agustus 2007 yaitu melalui Inisiasi Menyusu Dini (IMD). Pemberian Air Susu Ibu (ASI) sejak dini dapat memberikan efek perlindungan pada bayi dan balita dari penyakit infeksi. Oleh karena itu, disarankan untuk memberi ASI bagi bayi segera mungkin yaitu dalam waktu 1 jam sesaat setelah bayi lahir (Roesli, 2008).

Dua puluh empat jam pertama setelah ibu melahirkan adalah saat yang sangat penting untuk keberhasilan menyusui selanjutnya. Pada jam-jam setelah melahirkan dikeluarkan hormon oksitoksin yang bertanggung jawab terhadap produksi ASI.Waktu pertama kali mendapatkan ASI segera setelah lahir secara bermakna meningkatkan kesempatan hidup bayi. Jika bayi mulai menyusu dalam waktu 1 jam setelah lahir, $22 \%$ bayi yang 
meninggal dalam 28 hari pertama (setara dengan sekitar satu juta bayi baru lahir setiap tahun di dunia) sebenarnya dapat dicegah. Jika proses menyusui ini dimulai dalam satu jam hari pertama, maka $16 \%$ bayi yang dapat diselamatkan (Profil Kesehatan Indonesia, 2013).

$$
\text { Inisiasi menyusu dini }
$$
merupakan proses bayi menyusu segera setelah dilahirkan, dimana bayi dibiarkan mencari puting susu ibunya sendiri (tidak disodorkanke puting susu).Menyusui sejak dini mempunyai dampak yang positif baik bagi ibu maupun bayinya, bagi bayi kehangatan saat menyusu menurunkan resiko kematian karena hypothermia (kedinginan). Selain itu juga, bayi memperoleh bakteri tak berbahaya dari ibu, menjadikannya lebih kebal dari bakteri lain di lingkungan. Dengan kontak pertama, bayi memperoleh kolostrum, yang penting untuk kelangsungan hidupnya, dan bayi memperoleh ASI (makanan awal) yang tidak mengganggu pertumbuhan, fungsi usus, dan alergi sehingga bayi akan lebih berhasil menyusu ASI eksklusif dan mempertahankan menyusu.Sedangkan manfaat bagi ibu adalah menyusu dapat mengurangi morbiditas dan mortalitas karena proses menyusu akan merangsang kontraksi uterus sehingga mengurangi perdarahan pasca melahirkan (postpartum) (Profil Kesehatan Indonesia, 2013).
Dengan melakukan Inisiasi Menyusu Dini, bayi belajar beradaptasi dengan kelahirannya di dunia. Bayi yang baru saja keluar dari rahim ibu, tentu merasa trauma ketika harus berada di dunia luar. Selain itu perpisahan antara ibu dengan bayinya bisa mengakibatkan daya tahan tubuh bayi menurun sehingga $25 \%$ sedangkan bila bayi bersama ibu, daya tahan bayi akan berada dalam kondisi prima (Lusi, 2008).

Hasil penelitian Sose dkk (1978) menyatakan bahwa terdapat hubungan antar kontak kulit ibu-bayi pertama kali terhadap lama menyusui. Bayi yang diberi kesempatan menyusu dini dengan meletakkan bayi kontak kulit ke kulit ibu setidaknya satu jam pertama dua kali lebih lama menyusui hasilnya 59\% dan 38\% menyusu sampai usia 6 bulan dan setahun sedangkan bayi yang tidak diberi kesempatan menyusu dini tidak terlalu lama menyusui hanya $29 \%$ dan $8 \%$ yang masih disusui dengan usia yang sama. Penelitian Fika dan Syafiq (2003) melaporkan bahwa bayi diberi kesempatan untuk menyusu dini hasilnya delapan kali lebih berhasil melakukan ASI Eksklusif (Roesli, 2008).

Direktur Bina Gizi Masyarakat Departemen Kesehatan, dr. Ina Hernawati MPH, menyatakan bahwa Inisiasi Menyusu Dini penting agar bayi mendapatkan kekebalan. Sebab saat bayi bersentuhan langsung 
dengan ibunya, bayi tertular kuman dan karena ibu telah memiliki kekebalan, kekebalan itu kemudian disalurkan ibu pada bayinya melalui pemberian ASI. Inisiasi Menyusu Dini juga bermanfaat agar ibu lebih mudah terstimulus menyusu. Bayi yang menyentuh dada ibu lebih mendapatkan rangsangan sensorik yang kemudian memerintahkan otak untuk memproduksi hormon oksitosin dan prolaktin. Jadi, secara otomatis semua ibu sebenarnya bisa menyusui (Ririn, 2007).

Pemerintah Indonesia

mendukung kebijakan WHO dan UNICEF yang merekomendasikan inisiasi menyusu dini sebagai tindakan "penyelamatan kehidupan", karena inisiasi menyusu dini dapat menyelamatkan $22 \%$ dari bayi yang meninggal sebelum usia satu bulan. Maka diharapkan semua tenaga kesehatan di semua tingkat pelayanan kesehatan dapat mensosialisasikan program tersebut (Profil Kesehatan Indonesia, 2013).

Pada kenyataannya dilapangan sulit sekali untuk melaksanakan inisiasi menyusu dini. Kesulitan ini terletak pada aspek sosial yang meliputi belum banyak yang mengetahui inisiasi menyusu dini terutama ibu hamil primigravida dan rumah sakit atau klinik beserta tenaga penolong pesalinan yang belum mengenal lebih jauh inisiasi menyusu dini, serta keengganan tenaga kesehatan untuk melakukan inisiasi menyusu dini.Selain itu kadang-kadang ibu keberatan untuk menyusui bayinya dengan alasan ASI belum keluar. Dalam hal ini ibu harus diberi penjelasan sebaikbaiknya tentang maksud dan tujuan pemberian ASI sedini mungkin (Sumarah dkk, 2009).

Jarangnya pelaksanaan Inisiasi Menyusu Dini, dan kesalahankesalahan dalam pelaksanaan kegiatan Inisiasi Menyusu Dini menyebabkan keberhasilan menyusui tidak optimal karena Inisiasi Menyusu Dini (IMD) dapat mengetahui apakah bayi akan mendapat cukup ASI atau tidak. Hasil Riskisdes 2013 mengatakan bahwa persentase proses mulai mendapatkan ASI kurang dari satu jam (inisiasi menyusu dini) pada anak umur 0-23 bulan di Indonesia pada tahun 2013 sebesar 34,5\%. Persentase proses mulai mendapat ASI antara 1- 6 jam sebesar 35,2\%, persentase proses mulai mendapat ASI 7 - 23 jam sebesar 3,7\%, sedangkan persentase proses mulai mendapat ASI antara $24-47$ jam sebesar $13,0 \%$ dan persentase proses mulai mendapat ASI lebih dari 47 jam sebesar $13,7 \%$. Sumatera Utara menduduki peringkat ke-4 terendah dari 33 provinsi di Indonesia untuk persentase proses mulai mendapatkan ASI kurang dari satu jam (inisiasi menyusu dini) yaitu sebesar 22,9 \% (Profil Kesehatan Indonesia, 2013).

Menyusu bayi di Indonesia sudah menjadi budaya namun 
praktek pemberian ASI masih jauh dari yang diharapkan. Persentase pemberian ASI ekskusif pada bayi 06 bulan di Indonesia pada tahun 2013 sebesar 54,3\%, sedikit meningkat bila dibandingkan dengan tahun 2012 yang sebesar 48,6\%. Sumatera Utara menduduki peringkat ke-4 terendah dari 33 provinsi di Indonesia untuk persentase pemberian ASI eksklusif pada bayi usia 0 - 6 bulan yaitu sebesar 41,26 $\%$. Padahal pemerintah menargetkan pencapaian ASI eksklusif sebesar 80 $\%$ (Dirjen Gizi dan KIA Kemenkes RI, 2014).

Setelah dilakukan studi pendahuluan di RSU Sundari Medanpada bulan Februari 2015 didapatkan data jumlah ibu hamil primigravida yang melakukan pemeriksaan ANC sebanyak 80 orang. Dari hasil wawancara yang dilakukan oleh peneliti pada10 orang ibu hamil primigravida di Rumah Sakit Umum Sundari Medan didapatkan data hanya 2 orang $(20 \%)$ yang mengetahui tentang Inisiasi Menyusu Dini dan 8 orang yang lain $(80 \%)$ tidak mengetahui tentang Inisiasi Menyusu Dini.

\section{PEMBAHASAN}

Insiasi Menyusu Dini (early initiation) atau permulaan menyusu dini adalah bayi mulai menyusu sendiri segera setelah lahir. Jadi sebenarnya bayi manusia seperti juga bayi mamalia lain mempunyai 3) kemampuan untuk menyusu sendiri.
Asalkan dibiarkan kontak kulit bayi dengan kulit ibunya, setidaknya selama satu jam segera setelah lahir. Cara bayi melakukan inisiasi menyusu dini ini dinamakan the breast crawl atau merangkak mencari payudara (Ambarwati \& Wulandari, 2009).

Menurut Depkes 2010 dalam Maryunani (2012) menyatakan bahwa Inisiasi Menyusu Dini merupakan proses dimana bayi mulai menyusu sendiri segera setelah lahir. Pada satu jam pertama bayi harus disusukan pada ibunya, bukan untuk pemberian nutrisi saja melainkan untuk belajar menyusu atau membiasakan menghisap puting susu dan mempersiapkan ibu agar mulai memproduksi ASI kolostrum.

\section{Manfaat Inisiasi Menyusu Dini}

Menurut Anik Maryunani (2012) manfaat Inisiasi Menyusu Dini dapat dijelaskan secara umum dan khusus yaitu:

\section{Manfaat Inisiasi Menyusu Dini Secara Umum}

1) Mencegah hipotermia karena dada ibu menghangatkan bayi dengan tepat selama bayi merangkak mencari payudara.

2) Bayi dan ibu menjadi lebih tenang, tidak stres, pernapasan dan detak jantung lebih stabil, dikarenakan oleh kontak antara kulit ibu dan bayi.

Imunisiasi Dini. Mengecap dan menjilat permukaan kulit ibu 
sebelum mulai mengisap puting adalah cara alami bayi mengumpulkan bakteri-bakteri baik yang ia perlukan untuk membangun sistem kekebalan tubuhnya.

\section{Manfaat Inisiasi Menyusu Dini}

\section{Secara Khusus}

1) Manfaat untuk Ibu

a) Meningkatkan hubungan khusus ibu dan bayi

b) Merangsang kontraksi otot rahim sehingga mengurangi resiko perdarahan sesudah melahirkan

c) Memperbesar peluang ibu untuk memantapkan dan melanjutkan kegiatan menyusui selama masa bayi

d) Mengurangi stres ibu setelah melahirkan

e) Mencegah kehamilan

f) Menjaga kesehatan ibu

2) Manfaat untuk Bayi

a) Mempertahankan suhu bayi tetap hangat

b) Menenangkan ibu dan bayi serta meregulasi pernafasan dan detak jantung

c) Kolonisasi bakteri dan usus bayi dengan bakteri badan ibu yang normal (bakteri yang berbahaya dan menjadikan tempat yang baik bagi bakteri yang menguntungkan) dan mempercepat pengeluaran kolostrum sebagai antibody bayi.

\section{Manfaat secara Psikologis}

1) Adanya ikatan emosi (emotional bonding)

a) Hubungan ibu - bayi lebih erat dan penuh kasih sayang.

b) Ibu merasa lebih bahagia.

c) Bayi lebih jarang menangis.

d) Ibu berperilaku lebih peka (affectionately).

e) Lebih jarang menyiksa bayi (child abused).

2) Perkembangan: anak menunjukkan uji kepintaran yang lebih baik di kemudian hari.

\section{Langkah - Langkah Inisiasi Menyusu Dini}

Menurut Anik Maryunani (2012) langkah - langkah Inisiasi Menyusu Dini dapat dilakukan pada persalinan spontan maupun seksio sesar bahkan dapat juga pada bayi yang lahir kembar dan prematur. Langkah - langkahnya adalah sebagai berikut :

Langkah-Langkah

Inisiasi

Menyusu Dini pada Persalinan Spontan

1) Dianjurkan suami atau keluarga mendampingi ibu di kamar bersalin. Dalam menolong ibu melahirkan disarankan untuk mengurangi/tidak menggunakan obat kimiawi. 
2) Bayi lahir, segera dikeringkan secepatnya terutama kepala, kecuali tangan, tanpa menghilangkan vernix mulut dan hidung bayi dibersihkan, tali pusat diikat.

3) Bila bayi tidak memerlukan resusitasi, bayi ditengkurapkan di dada - perut ibu dengan kulit bayi melekat pada kulit ibu dan mata bayi setinggi puting susu. Keduanya diselimuti, bayi dapat diberi topi.

4) Anjurkan ibu menyentuh bayi untuk merangsang bayi. Biarkan bayi mencari puting sendiri.

\section{Langkah-Langkah Inisiasi Menyusu Dini pada Persalinan melalui OperasiSeksio Caesaria.}

1) Dianjurkan suami atau keluarga mendampingi ibu dikamar operasi atau dikamar pemulihan.

2) Begitu bayi lahir diletakkan di meja resusitasi untuk dinilai, dikeringkan secepatnya terutama kepala tanpa menghilangkan vernix; kecuali tangannya. Dibersihkan mulut dan hidung bayi, tali pusat diikat.

3) Kalau bayi tak perlu diresusitasi; bayi dibedong, dibawa ke ibu. Diperlihatkan kelaminnya pada ibu kemudian mencium ibu.

4) Tengkurapkan bayi di dada ibu dengan kulit bayi melekat pada kulit ibu. Kaki bayi agak sedikit serong/melintang menghindari sayatan operasi. Bayi dan ibu diselimuti. Bayi diberi topi.
Langkah-Langkah

Inisiasi

Menyusu Dini pada Bayi Kembar (Gemelli)

1) Dianjurkan suami atau keluarga mendampingi ibu dikamar bersalin.

2) Bayi pertama lahir, segera dikeringkan secepatnya terutama kepala, kecuali tangannya, tanpa menghilangkan vernix, mulut dan hidung bayi dibersihkan, tali pusat diikat.

3) Bila bayi tidak memerlukan resusitasi, bayi ditengkurapkan di dada-perut ibu dengan kulit bayi melekat pada kulit ibu di mata bayi setinggi puting susu. Keduanya diselimuti, bayi dapat diberi topi.

4) Anjurkan ibu menyentuh bayi untuk merangsang bayi. Biarkan bayi mencari puting sendiri.

\section{Langkah-Langkah}

Inisiasi

Menyusu Dini pada Bayi

\section{Prematur.}

1) Segera berikan ASI secepatnya setelah periode postpartum.

2) Tetapkan jadwal pemberian ASI, 8-10 kali dalam 24 jam, dengan interval tidak lebih dari 6 jam.

3) Gunakan sumber non-kimiawi untuk mengoptimalkan produksi ASI, misalnya massage payudara, hand expression, kontak kulit ke kulit. 
4) Cadangan ASI yang kurang harus diperhatikan setidaknya sampai hari ke-10.

Tahapan Perilaku (Preefeding Behavior) Sebelum Bayi Menyusu

Menurut Maryunani (2012), bayi baru lahir yang mendapatkan kontak kulit ke kulit segera setelah lahir, akan melalui 5 (lima) tahapan perilaku sebelum ia berhasil menyusu. Lima tahapan tersebut yaitu:

\section{Dalam 30-45 menit Pertama:}

1) Bayi akan diam dalam keadaan siaga

2) Sesekali matanya membuka lebar dan melihat ke arah ibunya

3) Masa ini merupakan masa peralihan dari keadaan dalam kandungan dan merupakan dasar pertumbuhan rasa aman bayi terhadap lingkungannya

\section{Antara 45-60 menit Pertama:}

1) Bayi akan mengerakkan mulutnya seperti mau minum, mencium, kadang mengeluarkan suara, dan menjilat tangannya

2) Bayi akan mencium dan merasakan cairan ketuban yang ada ditangannya

3) Bau ini sama dengan cairan yang dikeluarkan payudara ibu dan bau serta rasa ini yang akan membimbing bayi untuk menemukan payudara dan puting susu ibu.

\section{Mengeluarkan Liur:}

Saat bayi siap dan menyadari ada makan disekitarnya, bayi mulai mengeluarkan liur.

\section{Bayi Mulai Bergerak Ke Arah} Payudara:

1) Areola payudara akan menjadi sasarannya dengan kaki bergerak menekan perut ibu

2) Bayi akan menjilat kulit ibu, menghentakkan kepala ke dada ibu, menoleh ke kanan dan kiri, serta menyentuh dan meremas daerah puting susu dan sekitanya dengan tangannya.

\section{Menyusu:}

Akhirnya bayi menemukan, menjilat, mengulum puting, membuka mulut lebar-lebar, dan melekat dengan baik serta mulai menyusu.

\section{Faktor yang Mendukung Inisiasi} Menyusu Dini

Kesiapan fisik dan psikologi ibu sudah harus dipersiapkan sejak awal kehamilan. Hal yang menjadi faktor pendukung bagi kelancaran proses pemberian Inisiasi Menyusu Dini sesaat setelah lahir, harus dipersiapkan sejak masa ibu hamil. Menurut Maryunani (2012) ada 5 hal yang dapat menjadi faktor pendukung inisiasi menyusu dini yaitu sebagai berikut: 
Pengetahuan yang Diperoleh Ibu Mengenai Inisiasi Menyusu Dini

Informasi sangat penting dalam memberikan pengetahuan bagi ibu dalam melakukan inisiasi menyusu dini pada bayinya sesaat sesudah lahir. Menurut Rogers (1974) dalam Sunaryo (2004), informasi yang diperoleh akan dapat mengubah perilaku seseorang dengan suatu proses sebagai berikut:

1) Awareness (kesadaran) : individu menyadari adanya stimulus.

2) Interest (tertarik) : individu mulai tertarik pada stimulus.

3) Evaluation (menimbangnimbang) : individu menimbangnimbang tentang baik atau tidaknya stimulus tersebut bagi dirinya.

\section{Sikap Ibu}

Sikap merupakan respon seseorang terhadap stimulus atau objek tertentu, yang sudah melibatkan faktor pendapat dan emosi yang bersangkutan (Notoadmodjo, 2012). Oleh sebab itu, sikap dapat mempengaruhi perilaku ibu dalam melakukan inisiasi menyusu dini kepada bayinya.

\section{Tenaga Kesehatan}

Setiap ibu yang hendak melahirkan harus diinformasikan dan membimbing ibu-ibu mengenai hal kebutuhan atau hal yang kemungkinan akan terjadi dalam proses persalinan. Peran tenaga kesehatan yaitu memberikan informasi dan bimbingan tersebut harus bekerja sama dengan ibu yang hendak melahirkan tentang pentingnya informasi mengenai menyusukan bayi sesaat setelah lahir (Rukiyah, 2012).

\section{Sarana Kesehatan}

Ketika bayi dilahirkan sangat dibutuhkan sarana kesehatan yang mencukupi, tetapi untuk kegiatan inisiasi menyusu dini dapat menghemat ruangan untuk perawatan ibu dan bayi, karena ibu dan bayi berada di ruangan yang sama dalam melakukan inisiasi menyusu dini.

\section{Dukungan Keluarga}

Dalam kegiatan untuk inisiasi menyusu dini diperlukan dukungan keluarga. Keberhasilan inisiasi menyusu dini didukung oleh peranan keluarga dalam memberikan arahan dan bimbingan yang positif dari tercapai kegiatan inisiasi menyusu dini ibu dan bayinya sesaat sesudah lahir.

\section{Pengetahuan}

Pengetahuan adalah hasil pengindraan manusia, atau hasil tahu seseorang terhadap objek melalui indra yang dimilikinya (mata, hidung, telinga, dan sebagainya). Dengan sendirinya pada waktu pengindraan sehingga menghasilkan pengetahuan tersebut sangat dipengaruhi oleh intensitas perhatian 
dan persepsi terhadap objek. Sebagian besar pengetahuan seseorang diperoleh melalui indra pendengaran (telinga), dan indra penglihatan (mata)(Notoadmodjo S, 2010).

\section{Tingkat Pengetahuan}

$$
\text { Menurut Notoadmodjo }
$$

(2012), pengetahuan seseorang terhadap objek mempunyai intensitas atau tingkat yang berbeda-beda. Secara garis besar dibagi dalam 6 tingkat pengetahuan, yaitu :

\section{Tahu (Know)}

Tahu diartikan sebagai suatu kemampuan untuk mengingat kembali (recall) suatu materi yang sebelumnya, yakni mengingat kembali secara spesifik dari seluruh bidang yang dipelajari atau yang dirangsang kemudian diterimanya. Oleh sebab itu, "tahu" merupakan tingkat pengetahuan yang paling rendah.

\section{Memahami (Comprehention)}

Memahami diartikan sebagai suatu kemampuan untuk menjelaskan secara benar tentang objek yang diketahui dan dapat menyimpulkan, menjelaskan dan sebagainya dari objek yang dipelajari.

\section{Analisis (Analysis)}

Analisis adalah suatu kemampuan untuk menjabarkan materi atau objek ke dalam komponen tetapi masih ada kaitannya satu sama lain, misalnya dapat menggambarkan, membedakan, memisahkan dan sebagainya.

\section{Aplikasi (Application)}

Aplikasi diartikan sebagai kemampuan untuk menggunakan materi yang telah dipelajari pada situasi atau kondisi yang sebenarnya (nyata).

\section{Sintesis (Syntesis)}

Sintesis artinya kemampuan untuk melakukan atau menggabungkan bagian- bagian di dalam suatu bentuk keseluruhan yang baru. Dengan kata lain sintesis adalah ulusan yang merupakan suatu kemampuan untuk menyusun formulasi yang baru dari formulasi yang ada.

\section{Evaluasi (Evaluation)}

Evaluasi adalah kemampuan untuk melakukan penelitian terhadap suatu materi atau objek. Penilaian-penilaian itu didasarkan pada kriteria yang ditentukan sendiri atau menggunakan kriteria yang ada.

\section{Faktor-Faktor yang Memengaruhi Pengetahuan}

Menurut (Mubarak, 2007) ada tujuh faktor-faktor yang memengaruhi pengetahuan seseorang, yaitu : 


\section{a. Pendidikan}

Pendidikan berarti bimbingan yang diberikan seseorang pada orang lain terhadap sesuatu hal agar mereka dapat memahami. Tidak dapat dipungkiri bahwa makin tinggi pendidikan seseorang semakin mudah pula mereka menerima informasi, dan pada akhirnya makin banyak pula pengetahuan yang dimilikinya. Sebaliknya, jika seseorang tingkat pendidikannya rendah, akan menghambat perkembangan sikap seseorang terhadap penerimaan, informasi dan nilai-nilai yang baru diperkenalkan.

\section{Pekerjaan}

Lingkungan pekerjaan dapat menjadikan seseorang memperoleh pengalaman dan pengetahuan baik secara langsung maupun secara tidak langsung.

\section{Umur}

Dengan bertambahnya umur seseorang akan terjadi perubahan pada aspek psikis dan psikologis (mental). Pertumbuhan fisik secara garis besar ada empat kategori perubahan yaitu: perubahan ukuran, perubahan proporsi, hilangnya ciriciri lama, timbulnya ciri-ciri baru. Ini terjadi akibat pematangan fungsi organ. Pada aspek psikologis dan mental taraf berfikir seseorang semakin matang dan dewasa.
Minat

Minat sebagai suatu kecenderungan atau keinginan yang tinggi terhadap sesuatu. Minat menjadikan seseorang untuk mencoba dan menekuni suatu hal dan pada akhirnya diperoleh pengetahuan yang lebih mendalam.

\section{Pengalaman}

Pengalaman adalah suatu kejadian yang pernah dialami seseorang dalam berinteraksi dengan lingkungannya. Ada kecenderungan pengalaman yang kurang baik seseorang akan berusaha untuk melupakan, namun jika pengalaman terhadap obyek tersebut menyenangkan maka secara psikologis akan timbul kesan yang membekas dalam emosi sehingga menimbulkan sikap positif.

\section{b. Kebudayaan Sekitar}

Apabila dalam suatu wilayah mempunyai budaya untuk menjaga kebersihan lingkungan maka sangat mungkin masyarakat sekitarnya mempunyai sikap untuk selalu menjaga kebersihan lingkungan.

\section{Informasi}

$\begin{array}{lr}\text { Kemudahan memperoleh } \\ \text { informasi dapat membantu } \\ \text { mempercepat } & \text { seseorang } \\ \text { untukmemperoleh pengetahuan yang } \\ \text { baru. }\end{array}$


PENUTUPAN

\section{Kesimpulan}

Berdasarkan hasil penelitian yang dilakukan di Rumah Sakit Umum Sundari Medan dapat disimpulkkan mayoritas pengetahuan ibu primigravida tentang inisiasi menyusu dini kurang yaitu sebanyak 42 orang $(64,6 \%)$ dan minoritas pengetahuan ibu primigravida tentang inisiasi menyusu dini baik yaitu sebanyak 10 orang $(15,4 \%)$.

\section{DAFTAR PUSTAKA}

Profil Kesehatan Indonesia, (2013). Kesehatan Anak dan Status Gizi. Jakarta: Kemkes RI.

Nursalam, (2008). Konsep dan Penerapan Metodologi Penelitoian Ilmu Keperawatan. Jakarta: Salemba Medika.

Notoatmodjo, Soekidjo. (2010). Ilmu Perilaku Kesehatan. Jakarta: Rhineka Cipta.

Hidayat, A A, (2009). Metode Penelitian Keperawatan dan Teknik Analisi Data. Jakarta: Pustaka Belajar.

Hidayat, A. A, (2010). Metode Penelitian Kebidanan dan Teknik Analisa Data. Jakarta: Salemba Medika.

SDKI, (2012).Badan Pusat Statisik Kependudukan dan Keluarga Bencana Nasional Kementrian Kesehatan. Jakarta.
Setiadi, (2007). Konsep dan Penulian Riset Keperawatan. Yogyakarat: Graha Ilmu.

Sugiyono, (2012). Metode Penelitian Kuantitatif, Kualitatif, Dan $R \& D$. Bandung: Alfabeta.

Dwilistyowati, Lita. (2010). Manfaat dan Penghambat Inisiasi Menyusu Dini. Diambil tanggal 26 Desember 2014 dari http://sahabatperawat.com/201 2/07/manfaat-dan-penghambatinisiasi-menyusu-diniimmd/html. 